\title{
Physiological and biochemical activities of cherelle wilt on three cocoa clones (Theobroma cacao) under two levels of soil fertilities
}

\author{
ENDANG SRI DEWI HS ${ }^{1,2, \vartheta}$, PRAPTO YUDONO ${ }^{3}$, EKA TARWACA SUSILA PUTRA ${ }^{3}$, \\ BENITO HERU PURWANTO ${ }^{3}$ \\ ${ }^{1}$ Doctoral Program, Departement of Agrotechnology, Faculty of Agriculture, Universitas Gadjah Mada. Jl. Flora No. 1, Bulaksumur, Sleman 55281, \\ Yogyakarta, Indonesia. Tel./Fax.: +62-274-563062, `email: sridewihs83@gmail.com \\ ${ }^{2}$ Departement of Agrotechnology, Faculty of Agriculture, Universitas Sintuwu Maroso. J1. Pulau Timor No.1, Gebang Rejo, Poso 94612, Central \\ Sulawesi, Indonesia \\ ${ }^{3}$ Departement of Agrotechnology, Faculty of Agriculture, Universitas Gadjah Mada. Jl. Flora No. 1, Bulaksumur, Sleman 55281, Yogyakarta, Indonesia
}

Manuscript received: 14 November 2019. Revision accepted: 19 December 2019.

\begin{abstract}
Dewi HS ES, Ydono P, Putra ETS, Purwanto BH. 2020. Physiological, biochemical activities of cherelle wilt on three cocoa clones (Theobroma cacao) under two levels of soil fertilities. Biodiversitas 21: 187-194. Cherelle wilt is one of the diseases caused by physiological disorders. It results in loss of young pods by $70-90 \%$. This study aims to reveal the correlation of physiological and biochemical activities of several cocoa clones with two soil fertility status. The study was conducted using a nested design with two blocks as replications. The soil fertility status was classified based on soil chemical status. This obtained two clusters of soil fertility, namely low soil fertility and high soil fertility. The second factor was cocoa clone, consisting of three clones, namely RCC 70, RCC 71 and KKM 22. Variables measured were soil character, biochemistry of fresh and wilting cherelles, physiological activities, cherelle wilt and biochemical activities including sucrose content, reducing sugar and invertase activity. The data obtained were analyzed for their variance (ANOVA) with a 95\% confidence level and tested using Tukey's HSD there were significant differences between treatments. The results showed that high soil fertility status could increase contents of N, P, K and boron in leaves, increase nitrate reductase activity, chlorophyll contents, increase photosynthesis rate, suppress transpiration rate, increase assimilate transport from leaves to cherelle, increase enzyme invertase activity. RCC 70 clone indicated better physiological and biochemical activity and had the smallest percentage of cherelle wilt. Soil fertility status can suppress cherelle wilt by up to $60 \%$ through increasing physiological and biochemical activity. The RCC 70 clone shows the lowest cherelle wilt values compared to RCC 71 and KKM 22 clones.
\end{abstract}

Keywords: Biochemical, cocoa, cherelle wilt, physiology, soil fertility

\section{INTRODUCTION}

Cocoa is an important crop. Cocoa bean is raw material for making various processed food and beverage products (Guehi et al. 2007); as well as cosmetics and drugs (Anvoh et al. 2009). It contains catechin, theobromine, oleic acid, alantonin and vitamin $\mathrm{E}$ so that it can be used as anticarcinogenic, anti-atherogenic, vasodilatory and antioxidant (Steinberg et al. 2003; Engler et al. 2004; Grassi et al. 2005; Keen Holt et al. 2005; Raventos et al. 2005; Buijsse et al. 2006; Afoakwa et al. 2007; Kim et al. 2011; Andujar et al. 2012). Furthermore, it was reported that antioxidant content in cocoa is higher than that in green tea (Gunalan et al. 2010). The benefits of cocoa plants are enormous, but the problems encountered by farmers are also complicated. One of the problems is a physiological disease called Cherelle wilt. Cherelle wilt results in the loss of young pods from $7 \%$ to $92.5 \%$ (Humprhries 1943; McKelvie 1956; Aneja et al. 1999; Prawoto 2000; Melnick et al. 2013).

Several studies have reported causes of cherelle wilt such as pollen incompatibility (Pound 1932, Humphries 1943), water and mineral competition (Humphries 1943; 1947; 1950), phytohormone (McKelvie 1960; McKelvie 1956; Prawoto 1999), xylem occlusion (Nichols 1961), micronutrient deficiency (Wachjar 2005), and assimilate competition (Wachjar 2005; Astuti et al. 2011). Current studies of cherelle wilt particularly focus on assimilate competition and effects of phytohormone, but they have not obtained clear information about the causes of cherelle wilt. Humphries (1947) states that cherelle wilt is completely unrelated to assimilate competition. Humphries has detailed works from 1943 to 1950 which explain in detail that the limiting factors of cherelle wilt are water, minerals and inorganic nutrition. One of the factors that lower water, minerals, and nutrients are low soil fertility, especially chemical properties of the soil. Soil fertility indicates the ability of the soil to provide nutrients and water in order to support plant growth and development. Some elements that are strongly suspected to be the causes of cherelle wilt are potassium, phosphorus, and boron. They affect the photosynthetic activity in leaves and biochemical activity in fruits. In addition to the soil fertility, clone seems to be one of the important things to take into consideration because the response of the clones to the environment will determine the level of cherelle wilt in cocoa (Prawoto et al. 2015). This study was conducted to confirm the aforementioned statements, especially regarding the limiting factors for cherelle wilt, and the role of soil fertility, especially the role of the elements $\mathrm{P}, \mathrm{K}$, and 
Boron in lowering the ratio of cherelle wilt and the response of each clone to cherelle wilt in each respective soil fertility status.

\section{MATERIALS AND METHODS}

\section{Study area}

Plants taken as samples were fresh plants and had the same level of uniformity. This study used 3 clones, consisting of RCC 70, RCC 71 and KKM 22. It took place at a cocoa plantation, PT Pagilaran, Production Unit of Segayung Utara at Simbangjati Village, Tulis Subdistrict, Batang District, Central Java Province, Indonesia.

\section{Procedures}

Field experiments were designed using a nested design with two different statuses of soil fertility, namely high soil fertility status and low soil fertility status. The soil fertility status was determined based on cluster analysis in accordance with chemical properties of the land existing in the plantation. Each selected location was then divided into 3 blocks as replications with 5 plants per clone, so that there were 95 plants used in this observation.

Observed variables for soil analysis were divided into:

Soil characteristics include N-available, K-available, Pavailable, moisture content levels, types of soil, and soil $\mathrm{pH}$. The available $\mathrm{N}$ was determined Kjeldahl Method (Anon 2005), $\mathrm{P}$ and $\mathrm{K}$ determined by Olsen extraction (Olsen and Sommers 1982), Boron determine by MorganWolf extraction and organic carbon was determined by wet oxidation method (Anon 2005).

Physiological characteristics include N, P, K and boron contents in leaves, nitrate reductase, chlorophyll content, intercellular $\mathrm{CO}_{2}$, stomata density, stomatal conductance, photosynthetic rate, and transpiration rate. They were observed in leaves exposed to sunlight. Stomata observation: Stomata were taken by applying clear nail polish to 3rd or 4th leaves exposed to sunlight. After it was dry, the nail polish was removed using clear plaster and put on a glass object and then examined using a microscope. The number of stomata was observed using the ocular equipped with a net-shaped micrometer using 100x magnification. The width of the stomata opening was observed using a microscope with a micrometer magnification of 420x. Chlorophyll content: Chlorophyll content was measured using the spectrophotometric method of Harbon ${ }^{24}$. 0.1 gram of leaf was mashed using mortal and then extracted with $50 \mathrm{~mL}$ of $80 \%$ acetone. The samples were then filtered using filter paper in an Erlenmeyer flask. Absorbance was measured using a spectrophotometer at wavelengths of $663 \mathrm{~nm}$ and $646 \mathrm{~nm}$, while the blank used $80 \%$ acetone. Afterwards, the chlorophyll content was calculated using the formula: Chlorophyll $\mathrm{a}=12.21 \mathrm{x}$ A663-2.81x A646 x 50; Chlorophyll b = 20.13 x A646$5.03 \times$ A663 $\times$ 50; and total chlorophyll content = chlorophyll a + chlorophyll b. Nitrate reductase activity: Nitrate reductase activity was measured by using spectrophotometric method. $0.2 \mathrm{~g}$ of leaf was cut into small pieces with a size of $0.5 \mathrm{~cm}$ and put into a dark bottle containing $5 \mathrm{~mL} 0.1 \mathrm{M}$ phosphate buffer ( $\mathrm{pH} 7.0$ ), and left for 24 hours. After that, it was replaced with a new buffer solution containing $0.1 \mathrm{~mL}$ of $5 \mathrm{M} \mathrm{NaNO} 3$ as a substrate, and incubated for 2 hours. After the incubation, filtrate was inserted into a tube containing $0.2 \mathrm{~mL}$ of $1 \%$ sulphanilamide into $3 \mathrm{~N} \mathrm{HCl}$ and $0.2 \mathrm{~mL} 0.02 \% \mathrm{~N}$ naphtylethylene and then waited until it was pink as a sign of the change of nitrate to nitrite by the nitrate reductase enzyme. After the color changed, they would be read on the spectrophotometer with a wavelength of $540 \mathrm{~nm}$. Intercellular $\mathrm{CO}_{2}$, photosynthetic and transpiration rate were measured using Phothosinthetic analyzer model LI6400 of LICOR Inc. Lincoln, Nebraska, USA.

Biochemical characteristics include sucrose, sugar reduction, and invertase activity, and percentage of cherelle wilt. 10 grams of fresh cherelle (young pod) and wilting cherelle were added with liquid nitrogen and then crushed until smooth. 0.5 grams of the smooth samples was taken and added with extraction buffer twice the volume of sample weight, and mixed until it became homogeneous. The solution was centrifuged at $10,000 \mathrm{rpm}, 4^{\circ} \mathrm{C}$ for 10 minutes and then the supernatant was taken. It was saved at $-20^{\circ} \mathrm{C}$. The activity of breaking enzyme down (hydrolysis) of sucrose was measured based on the amount of reducing sugar produced by the hydrolysis of sucrose. Invertase enzyme activity: It was measured using the method of Arai (Arai et al 1991), the reagent solution to measure the enzyme activity of the acid invertase (AI) contained 25 $\mathrm{mM}$ MOPS-NaOH (pH 5.5) and $100 \mathrm{mM}$ sucrose. $250 \mu \mathrm{L}$ reaction buffer was incubated at $30^{\circ} \mathrm{C}$ for 5 minutes. After 5 minutes, the enzyme sample was added with $50 \mu \mathrm{L}$ and vortexed. It was incubated at $30^{\circ} \mathrm{C}$ for 0 and 20 minutes, then $500 \mu \mathrm{L}$ DNS reagent was inserted. It was boiled for 10 minutes in boiling water. After cooling, it was measured using a spectrophotometer at $560 \mathrm{~nm}$. The protein content was measured by using the Bradford method (Bradford 1976). $15 \mu \mathrm{L}$ of sample was added with $1 \mathrm{~mL}$ of Bradford reagent and then mixed (separated). After approximately 10 minutes, the absorbance of the mixture was measured using a spectrophotometer at a wavelength of $595 \mathrm{~nm}$. The protein content was calculated using the regression equation from the standard protein curve of Bovine Serum Albumin (BSA). The sucrose of cocoa cherelle was extracted using ethanol and then evaporated using rotary evaporation and dissolved using water distillation (aquabidest). Sucrose content was measured using resorcinol at spectrophotometer $\lambda 520 \mathrm{~nm}$ (Botha and Black 2000).

\section{Data analysis}

Data on soil characteristics and comparison of fresh cherelle and wilting cherelle were analyzed using F-test and T-test. Meanwhile, data of physiological characteristics and components of results were analyzed using variance analysis (ANOVA) $(\alpha=5 \%)$ and followed with the Tukey test $(\alpha=5 \%)$. 


\section{RESULTS AND DISCUSSION}

\section{Soil characterization}

Soil chemical properties were analyzed to reveal the characteristics of chemical properties at the study site. Based on this analysis. Referring to the assessment results of soil analysis criteria (Balintan 2009), the status of $\mathrm{P}$ available in the soil fertility status was moderate (8-10 units) and in the low soil fertility status was low (5-7). Ntotal was low $(0.1 \%-0.2 \%), \mathrm{K}$ available was very low $(<8$ $\mathrm{ppm}$ ) and $\mathrm{pH}$ was acidic (4.5-5.5). Boron content in soil was different between high soil fertility status and low soil fertility that in the high soil fertility the boron content was moderate $(>0.5)$, while in the low soil fertility status was low $(<0.5)$.

Based on the results of the analysis of several soil parameters at two study sites that contained soil fertility status based on the biochemical properties of the soil, the two soil fertility levels indicated differences only in the content of boron, phosphorus, and potassium available while total $\mathrm{N}, \mathrm{pH}$, organic matter, organic $\mathrm{C}$, soil acidity status and moisture content levels remained homogeneous.

\section{Leaf nutrient content (g. $\mathrm{g}^{-1} \mathrm{DW}$ ) and physiological activity}

The treatment of soil fertility status did not indicate a significant difference in leaf $\mathrm{N}$ content, but it indicates a difference in the absorption of $\mathrm{P}, \mathrm{K}$ and Boron in which high soil fertility status showed higher absorption than low soil fertility status. The differences in absorption occurred due to differences in levels of nutrient availability in the soil. Table 1 shows that the availability status of $\mathrm{P}, \mathrm{K}$ and Boron was indeed higher in high soil fertility status while $\mathrm{N}$ total was at the same level. The treatment of the clones indicated a significant difference in the absorption of $\mathrm{N}$ content. KKM 22 and RCC 70 clone indicated a higher absorption in high soil fertility status and RCC 71 clone lowest absorption. The low soil fertility status not be indicated significant differences of $\mathrm{N}$ content of three of clone. RCC 70 clone indicated higher total K, P, and boron in both types of soil fertility status. However, the three clones showed a decrease in total $\mathrm{N}, \mathrm{P}, \mathrm{K}$ and Boron content by $33.30 \%, 49.71 \%, 40.96 \%$, and $59 \%$, respectively. Low nutrient absorption in low soil fertility status was because of lower availability of soil nutrients (Table 1). This is consistent with (Marschners 2012) who argues that plants will absorb nutrients well if the condition of plants is healthy and the availability of nutrients in the soil is sufficient. Furthermore, nutrients control various processes that occur in plants so that it becomes a major limiting factor in plant growth and development.

Increased nutrient absorption, especially $\mathrm{P}, \mathrm{K}$ and boron in high soil fertility status and RCC 70 clone, affected nitrate reductase activity and chlorophyll a, b and total content (Table 2). Nitrite is a substrate that will be transformed by nitrate reductase enzyme into nitrate; Nitrate in plants is obtained from the absorption of the element $\mathrm{N}$, in this case, what is measured is the $\mathrm{N}$ total of the leaves. Nitrate reductase activity is strongly affected by enzymes and substrate precursors. In order to transform nitrate into nitrite, the nitrate reductase enzyme will transfer six electrons for each molecule (Ringer et al 2013). The electron transfer requires water and energy, the $\mathrm{P}$ element provides energy in the form of NADPH2 and $\mathrm{K}$ regulates cell turgidity, while Boron plays a role in permeability cells so that the process can run well. The increase and decrease in nitrate reductase activity due to deficiency and excess of boron have been reported in sunflower (Kastori et al. 1989); tobacco (Cristobal et al. 1999); peppers and tomatoes are grown in vitro (Eraslan et al. 2007); soybean (Hemantaranjan and Trivedi 2015). Therefore, although the substrate concentration is equal because the leaf $\mathrm{N}$ content is not different, the nitrate reductase activity in the high soil fertility status is higher than in the low soil fertility status. This is due to the availability of leaf $\mathrm{P}, \mathrm{K}$ and Boron in the high soil fertility status is higher than in the low soil fertility status. Similarly, RCC 70 clone indicated higher Nitrate reductase activity than RCC 71 and KKM22 clones. This increased activity of nitrate reductase directly affected the leaf chlorophyll content formed. The results of the correlation between nitrate reductase activity and leaf chlorophyll content in chlorophyll a, b and total levels indicated a positive correlation with $\mathrm{R}$ values of $0.85,0.57$ and 0.58 , respectively (Table 6). This means that any increase in nitrate reductase activity will be followed by an increase in leaf chlorophyll content. Thus, it means that in addition to directly affecting the increase in chlorophyll levels, soil fertility status also affects chlorophyll content through nitrate reductase activity.

The treatment of high soil fertility status indicated higher chlorophyll levels than low soil fertility status (Table 3). The highest levels of chlorophyll a and total chlorophyll in high soil fertility status were shown by RCC 70 and KKM 22 clones. Meanwhile, RCC 71 clone indicated lower level of chlorophyll-a and total chlorophyll. In the low soil fertility status, the three clones did not indicate any significant difference in chlorophyll content. This occurred because the three clones experienced chlorophyll content reduction when planted at low soil fertility status. Low level of chlorophyll is associated with nutrient absorption. Higher nutrient absorption in high soil fertility status made the three clones able to synthesize the proteins and amino acids needed for the formation of chlorophyll content in leaves. Unlike the case with low soil

Table 1. Analysis of various soil parameters at two locations with different levels of potassium (K) availability

\begin{tabular}{lll}
\hline Soil chemical character & High & Low \\
\hline $\mathrm{P}_{2} \mathrm{O}_{5}$ available $(\mathrm{ppm})$ & $8.06^{*}$ & $5,99^{*}$ \\
$\mathrm{~N}$ total soil content $(\%)$ & $0.12^{\mathrm{ns}}$ & $0.15^{\mathrm{ns}}$ \\
$\mathrm{K}$ available (ppm) & $1.03^{*}$ & $0.29^{*}$ \\
$\mathrm{~B}$ available (ppm) & $0.106^{*}$ & $0.043^{*}$ \\
Moisture content levels & $23.91^{\mathrm{ns}}$ & $22.15^{\mathrm{ns}}$ \\
$\mathrm{pH}$ & $5.25^{\mathrm{ns}}$ & $5.15^{\mathrm{ns}}$ \\
$\mathrm{C}$ organic & $1.49^{\mathrm{ns}}$ & $1.4^{\mathrm{ns}}$ \\
Organic matter $(\%)$ & $2.57^{\mathrm{ns}}$ & $2.55^{\mathrm{ns}}$ \\
Soil status & Acid & Acid \\
\hline
\end{tabular}

Note: (*) Significantly different, (ns) not significantly 
fertility status, nutrient absorption has not been able to increase chlorophyll levels in the leaves of the three clones. Several studies reported that several nutrients play an important role in the increase and degradation of chlorophyll, including nitrogen (Zang et al. 2017), phosphorus (Sannazzaro et al. 2006; Jiang et al. 2007; Colla et al. 2008); potassium (Percy et al. 2016; Zao et al. 2016; Hu et al. 2017; Zang et al. 2017;) and boron (Kitir et al. 2018; Hagazi et al. 2018).

High chlorophyll content in high soil fertility status allows greater absorption of photons. Photons are the spectrum of light that will be used to convert $\mathrm{CO}_{2}$ and $\mathrm{H}_{2} \mathrm{O}$ into chemical energy. The higher levels of chlorophyll, the larger the amount of photons will be absorbed and photosynthesis will increase. The results show that different chlorophyll content and different intercellular $\mathrm{CO}_{2}$ concentrations affect other physiological processes, namely photosynthesis, and transpiration. Zakariyya and Prawoto (2002) and explain that photosynthesis has a close correlation with chlorophyll content. Photosynthesis involves two reactions, dark reaction, and light reaction. The light reaction process depends on the chlorophyll content. According to Banyo and Ai (2011), this is because high chlorophyll content makes more photons absorbed so that the photosynthetic rate is higher. Furthermore, the dark reaction requires $\mathrm{CO}_{2}$ to be converted into sucrose compounds (Avianto 2017). Chlorophyll levels, especially chlorophyll a, have a positive correlation with increased stomata density and $\mathrm{CO}_{2}$ content in leaves. The $\mathrm{CO}_{2}$ content in leaves is another element that is highly needed in the process of photosynthesis. Table 4 shows that $\mathrm{CO}_{2}$ levels in leaves at high soil fertility status are greater than those at low soil fertility status. The RCC 70 clone shows higher $\mathrm{CO}_{2}$ content in leaves and photosynthetic rate than the two clones in both high soil fertility status and low soil fertility status (Table 4.) Another factor that causes high $\mathrm{CO}_{2}$ content is stomata density. The absorption of $\mathrm{CO}_{2}$ is inseparable from the stomatal density. The results of observation indicated that the width of the stomatal opening in low soil status is higher, but the stomatal density is lower; in contrast, in the high soil fertility status, the width of stomatal opening is narrower but the stomatal density is higher (Table 5). This condition increases the transpiration rate in low soil fertility status, but decreases the photosynthetic rate. Meanwhile, the transpiration rate decreases at high soil fertility status and the photosynthetic rate increases. The correlation between photosynthetic parameters is shown in Table 6.

The results show that the same clone if planted in a place that has different soil fertility conditions has different photosynthetic rates. Plants that grow at high soil fertility status have higher photosynthetic rates than those that grow at low soil fertility status (Table 4). High photosynthesis rate produces more assimilation, but low photosynthesis rate will produce lower assimilation. Assimilates are materials needed by plants for metabolic processes (Taiz and Ziger 2006).

Table 2. Nutrient content (g. $\left.\mathrm{g}^{-1} \mathrm{dw}\right)$ of three cocoa clones under two soil fertility status

\begin{tabular}{|c|c|c|c|c|c|c|c|c|}
\hline \multirow{3}{*}{ Clone } & \multicolumn{8}{|c|}{ Nutrient content $\left(\mathrm{g} . \mathrm{g}^{-1} \mathrm{dw}\right)$} \\
\hline & \multicolumn{2}{|c|}{$\begin{array}{c}\mathrm{N} \\
\text { Soil fertility status }\end{array}$} & \multicolumn{2}{|c|}{$\begin{array}{c}P \\
\text { Soil fertility status }\end{array}$} & \multicolumn{2}{|c|}{$\begin{array}{c}\text { K } \\
\text { Soil fertility status }\end{array}$} & \multicolumn{2}{|c|}{$\begin{array}{c}\text { B } \\
\text { Soil fertility status }\end{array}$} \\
\hline & High & Low & High & Low & High & Low & High & Low \\
\hline & $5.6730 \mathrm{a}$ & $5.4602 \mathrm{a}$ & $0.0076 \mathrm{a}$ & $0.0038 b$ & $0.0788 \mathrm{a}$ & $0173 b$ & $0.0253 \mathrm{a}$ & $0.0107 \mathrm{~b}$ \\
\hline RCC 70 & $0.3852 \mathrm{pq}$ & $0.2610 \mathrm{qr}$ & $0.0106 \mathrm{p}$ & $0.0053 \mathrm{pq}$ & $0.1040 \mathrm{p}$ & $0.0672 \mathrm{qr}$ & $0.0330 \mathrm{p}$ & $0.0180 \mathrm{qr}$ \\
\hline RCC 71 & $0.2546 \mathrm{qr}$ & $0.2006 \mathrm{r}$ & $0.0066 \mathrm{pq}$ & $0.0043 \mathrm{q}$ & $0.0608 \mathrm{qrs}$ & $0.0354 \mathrm{rs}$ & $0.0210 \mathrm{q}$ & $0.0063 \mathrm{r}$ \\
\hline KKM 22 & $0.3986 \mathrm{p}$ & $0.2110 \mathrm{r}$ & $0.0056 \mathrm{pq}$ & $0.0020 \mathrm{q}$ & $0.0715 \mathrm{q}$ & $0.0388 \mathrm{r}$ & $0.0220 \mathrm{q}$ & $0.0080 \mathrm{~s}$ \\
\hline
\end{tabular}

Note: Value on the same columns followed by the same letter were not significantly difference according to Tukey $5 \%$, (ns) indicated that there was no interaction between each factor.

Table 3. the activity of nitrate reductase $\left(\mu \mathrm{mol} \mathrm{NO} 2 \cdot \mathrm{g}^{-1} \cdot \mathrm{h}^{-1}\right)$, chlorophyll a, chlorophyll b, total chlorophyll content $\left(\mathrm{mg}^{\mathrm{g}} \mathrm{g}^{-1} \cdot \mathrm{dw}^{-1}\right)$ of three cocoa clone under two soil fertility status

\begin{tabular}{|c|c|c|c|c|c|c|c|c|}
\hline \multirow{3}{*}{ Clone } & \multirow{2}{*}{\multicolumn{2}{|c|}{$\begin{array}{l}\text { Nitrate reductase activity } \\
\left(\mu \mathrm{mol} \mathrm{NO}_{2 \cdot} \cdot \mathrm{g}^{-1} \cdot \mathbf{h}^{-1}\right) \\
\text { Soil fertility status }\end{array}$}} & \multicolumn{6}{|c|}{ Chlorophyll content $\left(\mathrm{mg} \cdot \mathrm{g}^{-1} \cdot \mathrm{dw}^{-1}\right)$} \\
\hline & & & \multicolumn{2}{|c|}{$\frac{a}{\text { Soil fertility status }}$} & \multicolumn{2}{|c|}{$\begin{array}{c}\text { b } \\
\text { Soil fertility status }\end{array}$} & \multicolumn{2}{|c|}{$\begin{array}{c}\text { Total } \\
\text { Soil fertility status }\end{array}$} \\
\hline & High & Low & High & Low & High & Low & High & Low \\
\hline & $2.1277 \mathrm{a}$ & $1.6750 \mathrm{~b}$ & $0.3461 \mathrm{a}$ & $0.2242 \mathrm{a}$ & $0.2165 \mathrm{a}$ & $0.1700 \mathrm{~b}$ & $0.5624 \mathrm{a}$ & $0.2941 \mathrm{~b}$ \\
\hline RCC 70 & $2.1426 \mathrm{p}$ & $1.5762 \mathrm{q}$ & $0.3856 \mathrm{pq}$ & $0.2642 \mathrm{pqr}$ & $0.2686 \mathrm{pq}$ & $0.1640 \mathrm{pq}$ & $0.6523 p$ & $0.2941 \mathrm{r}$ \\
\hline RCC 71 & $1.8595 \mathrm{pq}$ & $1.3890 \mathrm{q}$ & $0.2546 \mathrm{qr}$ & $0.2006 \mathrm{r}$ & $0.1980 \mathrm{pq}$ & $0.1406 \mathrm{q}$ & $0.4523 \mathrm{qr}$ & $0.4163 \mathrm{r}$ \\
\hline KKM 22 & $2.3464 \mathrm{p}$ & $1.3491 \mathrm{q}$ & $0.3986 \mathrm{p}$ & $0.2110 \mathrm{r}$ & $0.2053 \mathrm{p}$ & $0.1830 \mathrm{q}$ & $0.5813 \mathrm{pq}$ & $0.3413 \mathrm{r}$ \\
\hline
\end{tabular}

Note: Value on the same columns followed by the same letter were not significantly differenced according to Tukey $5 \%$, (ns) indicated that there was no interaction between each factor 
Table 4. Intercellular $\mathrm{CO}_{2}(\mathrm{mmol} \mathrm{CO})$, Photosynthetic rate $\left(\mu \mathrm{mol} \mathrm{CO} 2 \cdot \mathrm{m}^{2-1} \mathrm{~s}^{-1}\right)$ of three cocoa clones under two soil fertility status

\begin{tabular}{|c|c|c|c|c|}
\hline \multirow[t]{2}{*}{ Clone } & \multicolumn{2}{|c|}{$\begin{array}{c}\mathrm{CO}_{2} \text { intracellular }\left(\mathrm{mmol} \mathrm{CO}_{2}\right) \\
\text { Soil fertility status }\end{array}$} & \multicolumn{2}{|c|}{$\begin{array}{c}\text { Photosynthetic rate }\left(\mu \mathrm{mol} \mathrm{CO}_{2 \cdot} \cdot \mathrm{m}^{2-1} \mathrm{~s}^{-1}\right) \\
\text { Soil fertility status }\end{array}$} \\
\hline & High & Low & High & Low \\
\hline & $346.3118 \mathrm{a}$ & $315.6953 \mathrm{~b}$ & $151.9778 \mathrm{a}$ & $143.2667 \mathrm{~b}$ \\
\hline RCC 70 & $357.2367 \mathrm{p}$ & $322.5180 \mathrm{q}$ & $152.1333 p$ & $144.6000 \mathrm{p}$ \\
\hline RCC 71 & $353.9967 \mathrm{p}$ & $320.9967 \mathrm{q}$ & $152.0667 \mathrm{p}$ & $143.4667 \mathrm{q}$ \\
\hline KKM 22 & $327.7020 \mathrm{q}$ & $303.5713 \mathrm{q}$ & $151.7333 p$ & $141.7333 \mathrm{q}$ \\
\hline
\end{tabular}

Note: Value on the same columns followed by the same latter were not significant according to Tukey 5\%, (ns) indicated that there was no interaction between each factor

Table 5. Stomatal density (unit. $\left.\mathrm{mm}^{2-1}\right)$, Stomatal conductance $\left(\mathrm{mmol} \cdot \mathrm{m}^{-2} \cdot \mathrm{s}^{-1}\right)$, transpiration rate $\left(\mathrm{mmol} \mathrm{H}_{2} \mathrm{O} \cdot \mathrm{m}^{2} \cdot \mathrm{s}^{-1}\right)$ of three cocoa clones under two soil fertility status.

\begin{tabular}{|c|c|c|c|c|c|c|}
\hline \multirow[t]{2}{*}{ Clone } & \multicolumn{2}{|c|}{$\begin{array}{l}\begin{array}{l}\text { Stomatal density } \\
\left(\text { unit } \mathbf{m m}^{2-1}\right) \\
\text { Soil fertility status }\end{array}\end{array}$} & \multicolumn{2}{|c|}{$\begin{array}{c}\text { Stomatal conductance } \\
\left(\mathbf{m m o l} \cdot \mathbf{m}^{-2} \cdot \mathbf{s}^{-1}\right) \\
\text { Soil fertility status }\end{array}$} & \multicolumn{2}{|c|}{$\begin{array}{c}\text { Transpiration rate } \\
\left(\text { mmol } \mathrm{H}_{2} \mathrm{O} \cdot \mathbf{m}^{2-1} \cdot \mathbf{s}^{-}\right) \\
\text {Soil fertility status }\end{array}$} \\
\hline & High & Low & High & Low & High & Low \\
\hline & $1111.58 \mathrm{a}$ & $1000.64 \mathrm{~b}$ & $0.6183 \mathrm{a}$ & $0.6947 \mathrm{a}$ & $23.0108 \mathrm{~b}$ & $39.4586 \mathrm{a}$ \\
\hline RCC 70 & $1129.11 \mathrm{p}$ & $1060.50 \mathrm{pq}$ & $0.7513 p$ & $0.5996 \mathrm{p}$ & $21.7673 \mathrm{q}$ & $36.3163 \mathrm{p}$ \\
\hline RCC 71 & $1155.36 \mathrm{p}$ & $988.50 \mathrm{q}$ & $0.7513 \mathrm{p}$ & $0.6240 \mathrm{p}$ & $23.7816 \mathrm{q}$ & $42.7070 \mathrm{p}$ \\
\hline KKM 22 & $1050.33 \mathrm{pq}$ & $952.92 \mathrm{q}$ & $0.6510 \mathrm{p}$ & $0.5800 \mathrm{p}$ & $23.4833 \mathrm{q}$ & $39.3526 \mathrm{p}$ \\
\hline
\end{tabular}

Note: Value on the same columns followed by the same latter were not significant according to Tukey 5\%, (ns) indicate that there was no interaction between each factor

Table 6. Correlational analysis between variables of physiology

\begin{tabular}{|c|c|c|c|c|c|c|c|c|c|c|c|c|c|}
\hline & NR & chl a & chl b & $\operatorname{chl} \mathbf{T}$ & $\mathrm{Nc}$ & Pc & Kc & $\mathbf{B c}$ & Pn & $\mathbf{C i}$ & $\mathbf{E}$ & dS & $\mathbf{s C}$ \\
\hline NR & 1 & $* *$ & $*$ & $*$ & $\mathrm{~ns}$ & ns & ns & $*$ & ns & $*$ & $* *$ & ns & ns \\
\hline chl a & & 1 & $\mathrm{~ns}$ & $* *$ & $\mathrm{~ns}$ & ns & ns & $* *$ & $\mathrm{~ns}$ & $*$ & $* *$ & $*$ & $\mathrm{~ns}$ \\
\hline chl b & & & 1 & ns & ns & ns & ns & ns & ns & $-n s$ & ns & ns & ns \\
\hline $\operatorname{chl} \mathrm{T}$ & & & & 1 & $\mathrm{~ns}$ & ns & $\mathrm{ns}$ & $*$ & $\mathrm{~ns}$ & $*$ & $*$ & ns & ns \\
\hline $\mathrm{Nc}$ & & & & & 1 & ns & ns & ns & ns & ns & ns & ns & ns \\
\hline $\mathrm{Pc}$ & & & & & & 1 & ns & ns & ns & ns & $*$ & ns & ns \\
\hline $\mathrm{Kc}$ & & & & & & & 1 & ns & ns & ns & $\mathrm{ns}$ & $\mathrm{ns}$ & ns \\
\hline $\mathrm{Bc}$ & & & & & & & & 1 & ns & $*$ & $* *$ & $*$ & ns \\
\hline Pn & & & & & & & & & 1 & $* *$ & $\mathrm{~ns}$ & ns & ns \\
\hline $\mathrm{Ci}$ & & & & & & & & & & 1 & $*$ & $*$ & ns \\
\hline $\mathrm{E}$ & & & & & & & & & & & 1 & $*$ & $*$ \\
\hline $\mathrm{dS}$ & & & & & & & & & & & & 1 & $\mathrm{~ns}$ \\
\hline $\mathrm{sC}$ & & & & & & & & & & & & & 1 \\
\hline
\end{tabular}

Note: NR: Nitrate Reductase Activity, chl a: Chlorophyll a, chl b: Chlorophyll b, chl T: Total chlorophyll, Nc: Total leaf N content, Pc: Total leaf P content, Kc: Total leaf K content, Bc: Total leaf B content, Pn: Photosynthetic rate, Ci: Intercellular $\mathrm{CO}_{2}$, E: Transpiration, dS: Stomatal density, Sc: stomatal conductance, ns: Non-significant correlations

Percentage of cherelle wilt (\%) and biochemical activity (sucrose, sugar reduction content and Invertase activity) in the cherelle (\%)

Several studies have reported that one of the main causes of cherelle wilt is due to the competition of assimilates between organs that actively grow and the low assimilates (sucrose) that enters the cherelle resulting in the failure of cherelle development (Prawoto 2000; Astuti et al. 2011). In plants, the only producer of assimilates is leaves so that leaves are referred to as the source, while all parts of plants are referred to as users (sinks). Leaves produce assimilates through the process of photosynthesis. The assimilate results produced on the leaves are then transported by phloem to the cherelle in the form of sucrose. The movement of sucrose from the source to the sink after the phloem loading process takes place through osmosis (Taiz and Ziger 2006; Liesce et al. 2011). Because of the movement is osmotic, the sucrose status in the sink will affect the flow of sucrose from the source ( $\mathrm{Yu}$ et al. 2015). Sucrose from the source can be transported into the cherelle if (i) there is no disturbance in the phloem and (ii) The content of sucrose in the cherelle is lower than outside of the cherelle. Several studies have reported that one of the main causes of cherelle wilt is the assimilate competition between organs that actively grow and the low assimilate (sucrose) that enters the cherelle causes the failure of cherelle development (Prawoto 2000; Astuti et al. 2011). The percentage of cherelle wilt in the low soil 
fertility status is quite high by $62.27 \%$, while in the high soil fertility status is only $40.06 \%$, meaning that there is a difference of approximately $20 \%$ (Table 7). Previous observations indicated that soil fertility status greatly affects the photosynthetic machinery and thus directly increases the photosynthetic rate (Table 6).

The results showed that soil fertility status and clones did not indicate a significant difference in the content of sucrose and fructose of fresh cherelle, but indicated a significant difference in the content of sucrose and reducing sugar in cherelle wilt (Table 7 ). In the high soil fertility status and RCC 70 clone, the sucrose content of wilting cherelle is lower and the reducing sugar content is higher. This lower sucrose content is because the wilting cherelle in the high soil fertility status and the RCC 70 clone is still able to convert sucrose into reducing sugar although it is not as big as in fresh cherelle. The opposite results are shown in the low soil fertility status and two clones (RCC71 and KKM22). However, it should be noted that there are differences in the sucrose content in fresh cherelle and wilting cherelle both in low soil fertility and in high soil fertility (Table 8).

The correlation between wilting cherelle and photosynthesis is quite weak with a correlation value of0.42 , meaning that an increase in photosynthesis will be followed by an increase in wilting cherelle by 0.42 . This result indicates that physiological parameters, especially photosynthesis, correlate with wilting cherelle but the correlation is not significant. What is interesting is that the correlation between glucose and reducing sugar content in cherelle wilt has a significant correlation with values of 0.76 and-0.85, respectively (Table 9). Accordingly, the higher the sucrose in wilting cherelle is, the higher the percentage of wilting cherelle will be by $76 \%$ and, conversely, the higher the reducing sugar is, the lower the percentage of wilting cherelle will be by $85 \%$. The conversion of sucrose into reducing sugar is strongly affected by soil fertility status and clone response to soil fertility status, that nutrients required in the enzyme activity process that converts sucrose into reducing sugar are higher in the high soil fertility status and RCC 70 (Figure 1). Enzyme which plays a role in reducing sucrose to sucrose is invertase enzyme. Changes in the content of sucrose in the cherelle will affect the flow of sucrose. Because it does not convert, high sucrose content disturbs phloem loading. Sucrose does not experience changes of form because invertase enzyme activity undergoes metabolic disorders. Such metabolic disorder is due to reduced water content and low nutrient content in the cherelle. The availability of $\mathrm{K}$ in the cherelle is very closely related to invertase activity.

Table 7. Sucrose and reducing sugar content in fresh cherelle and wilting cherelle of cocoa clones under two-level soil fertility status.

\begin{tabular}{|c|c|c|c|c|c|c|c|c|c|c|}
\hline \multirow[t]{2}{*}{ Clone } & \multicolumn{2}{|c|}{$\begin{array}{c}\text { Percentage of cherelle } \\
\text { wilt }(\%) \\
\text { Soil fertility status }\end{array}$} & \multicolumn{2}{|c|}{$\begin{array}{c}\text { Sucrose } \\
(\%) \\
\text { Soil fertility status }\end{array}$} & \multicolumn{2}{|c|}{$\begin{array}{c}\text { Reducing sugar } \\
(\%) \\
\text { Soil fertility status }\end{array}$} & \multicolumn{2}{|c|}{$\begin{array}{c}\text { Sucrose } \\
(\%) \\
\text { Soil fertility status }\end{array}$} & \multicolumn{2}{|c|}{$\begin{array}{c}\text { Reducing sugar } \\
(\%) \\
\text { Soil fertility status }\end{array}$} \\
\hline & High & Low & High & Low & High & Low & High & Low & High & Low \\
\hline & $40.06 \mathrm{~b}$ & $62.27 \mathrm{a}$ & $4.92 \mathrm{a}$ & $4.30 \mathrm{a}$ & $0.51 \mathrm{a}$ & $0.47 \mathrm{a}$ & $3.48 \mathrm{~b}$ & $5.13 \mathrm{a}$ & $0.24 \mathrm{a}$ & $0.15 b$ \\
\hline RCC 70 & $61.03 \mathrm{ab}$ & $32.17 \mathrm{~d}$ & $4.71 \mathrm{a}$ & $4.63 \mathrm{a}$ & $0.52 \mathrm{a}$ & $0.48 \mathrm{a}$ & $4.60 \mathrm{ab}$ & $3.44 \mathrm{bc}$ & $0.25 \mathrm{a}$ & $0.16 \mathrm{~b}$ \\
\hline RCC 71 & $61.76 \mathrm{ab}$ & $48.20 \mathrm{bc}$ & $5.39 \mathrm{a}$ & $3.75 \mathrm{a}$ & $0.49 \mathrm{a}$ & $0.45 \mathrm{a}$ & $5.72 \mathrm{a}$ & $4.47 \mathrm{ab}$ & $0.22 \mathrm{ab}$ & $0.15 \mathrm{~b}$ \\
\hline $\begin{array}{l}\text { KKM } 22 \\
\text { Interaction }\end{array}$ & $\begin{array}{l}64.03 \mathrm{a} \\
\mathrm{ns}\end{array}$ & $\begin{array}{l}39.80 \mathrm{~cd} \\
\mathrm{~ns}\end{array}$ & $\begin{array}{l}4.76 \mathrm{a} \\
\mathrm{ns}\end{array}$ & $\begin{array}{l}4.45 \mathrm{a} \\
\mathrm{ns}\end{array}$ & $\begin{array}{l}0.50 \mathrm{a} \\
\mathrm{ns}\end{array}$ & $\begin{array}{l}0.47 \mathrm{a} \\
\mathrm{ns}\end{array}$ & $5.07 \mathrm{a}$ & $2.53 \mathrm{c}$ & $0.26 \mathrm{a}$ & $0.15 \mathrm{~b}$ \\
\hline
\end{tabular}

Note: Value on the same columns followed by the same latter were not significant according to Tukey 5\%, (ns) indicated that there was no interaction between each factor

Table 8. Comparison of sucrose and reducing sugar on fresh cherelle and wilting cherelle

\begin{tabular}{cccc}
\hline \multicolumn{1}{c}{ Parameter } & $\begin{array}{c}\text { Soil fertility } \\
\text { status }\end{array}$ & $\begin{array}{c}\text { Fresh } \\
\text { cherelle }\end{array}$ & $\begin{array}{c}\text { Wilting } \\
\text { cherelle }\end{array}$ \\
\hline Sucrose & High & $4.92^{*}$ & $3.48^{*}$ \\
\multirow{2}{*}{ Reducing sugar } & Low & $4.30^{*}$ & $5.13 *$ \\
& High & $0.51^{*}$ & $0.24 *$ \\
& Low & $0.47^{*}$ & $0.15 *$ \\
\hline
\end{tabular}

Note: (*) Significant difference according to T-Test $5 \%$.
Table 9. Correlation between percentage of cherelle, photosynthesis with sucrose and reducing sugar content in the cherelle

\begin{tabular}{lcccccc} 
& Pl & Sfc & Swc & SRfc & SRwc & Pn \\
\hline Pl & 1 & ns & $*$ & ns & $-*$ & $n s$ \\
Sf & & 1 & ns & ns & ns & ns \\
Sw & & & 1 & ns & $-*$ & ns \\
SRs & & & & 1 & ns & ns \\
SRw & & & & & 1 & ns \\
Pn & & & & & & 1 \\
\hline
\end{tabular}

Note: Pl: Percentage of cherelle wilt, Sfc: sucrose content in the fresh cherelle, Swc: sucrose content in the wilting cherelle, SRfc: sucrose reductions content in the fresh cherelle, SRwc: sucrose reductions content in the wilting cherelle, ns: non-significant correlations 


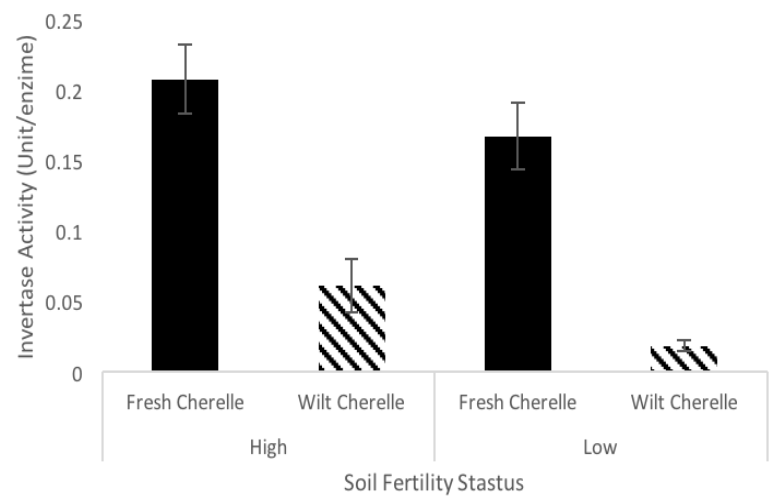

Figure 1. Invertase Activity under soil fertility status

Table 10. Regression of invertase activity with sucrose and reducing sugar

\begin{tabular}{cll}
\hline \multicolumn{1}{c}{ Variable X } & \multicolumn{1}{c}{ Variable $\mathbf{~}$} & \multicolumn{1}{c}{ Regression } \\
\hline Invertase activity & Sucrose content & $\mathrm{Y}=-0.0415 \mathrm{x}+0.2328 ;$ \\
& & $\mathrm{R}^{2}=0.65 *$ \\
Invertase activity & Reducing sugar & $\mathrm{Y}=1.8387 \mathrm{x}-0.7021 ;$ \\
& content & $\mathrm{R}^{2}=0.77 * *$ \\
\hline
\end{tabular}

The results show that soil fertility status and clone use affect physiological activity. The same clone shows different physiological activities when planted on different soil fertility status. RCC 70 clone consistently exhibits higher physiological activity both at high soil fertility status and at low soil fertility status. Wilting cherelle at high soil fertility status is lower than that at low soil fertility status. RCC 71 clone shows higher wilting cherelle than other clones. There is a correlation between physiological activity and wilting cherelle, but this correlation is not significant. Physiological activity is able to supply sucrose in healthy cherelle and wilting cherelle. However, it seems that wilting cherelle is more affected by biochemical activity. Wilting cherelle is able to convert sucrose into reducing sugar due to low enzyme invertase activity. Low invertase activity is correlated with the availability of nutrients, especially $\mathrm{K}$ and boron. The mechanism of potassium and boron in affecting the invertase activity and its correlation with wilting cherelle is being investigated in the research, which is a continuation of this research.

\section{ACKNOWLEDGEMENTS}

This study was supported by the Ministry of Research and Higher Education of the Republic of Indonesia through Graduate Team Grant Financial Year 2018 No 1176/UN1/DITLIT/DIT-LIT/2018. There is no conflict of interest resulted from this study.

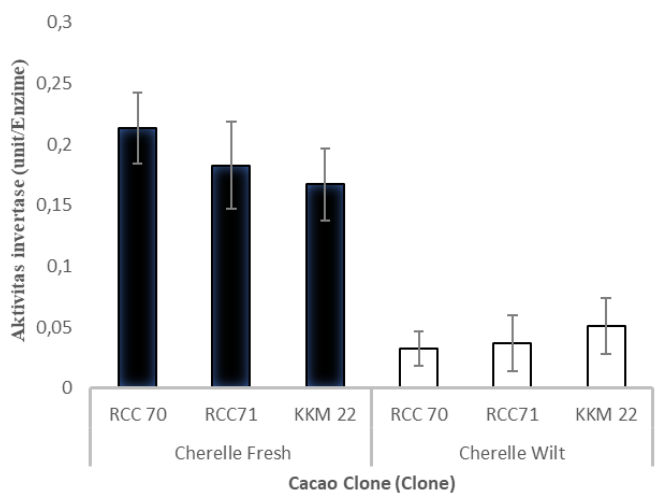

Figure 2. Invertase Activity cocoa clone

\section{REFERENCES}

Afoakwa EO, Peterson A, Flower M. 2007. Review: Factor influencing, texture, qualities in chocolate. Trens Food Technol 18: 290-298.

Andújar I, Recio MC, Giner RM, Ríos JL. 2012. Cocoa polyphenols, their potential benefits for human health - Review article. Oxidat Med Cell Longev. DOI: 10.1155/2012/906252.

Anon. 2005. Jurnal kimia. Balai Penelitian Tanah. Bogor. [Indonesia]

Anvoh KYB, Bi ZA, Gnarkri D. 2009. Production, characterization of juice from mucilages of cocoa beans, its transformation in to marmalade. Pak J Nutr 8 (2): 129-133.

Astuti YTM, Prawoto AA, Dewi K. 2011. Effect of flush existence, NAA, GA application on cocoa pod development. Pelita Perkebunan. 27 (1): 11-23. [Indonesian]

Astuti YTM. 2011. Alokasi Fotosintat dan Hormon sebagai Penyebab Layu Buah Mudah Kakao. [Disertasi]. Fakultas Biologi, UGM. Yogyakarta. [Indonesian]

Avianto Y. 2017. Pengaruh arah Lereng terhadap Aktivitas Fisiologis dan Kualitas Minyak Daun Cengkeh (Syzigium aromaticum) di Pegunungan Menoreh. [Hon. Thesis]. Fakultas Pertanian. Universitas Gajdah Mada, Yogyakarta. [Indonesian].

Banyo Y, Ai NS. 2011. Konsentrasi klorofil daun sebagai indikator kekurangan air pada tanaman. Jurnal Ilmiah dan Sains 11 (2):-. [Indonesia]

Botha FC dan Black KG. 2000. Sucrose phosphate synthase, sucrose synthase activity during maturation of internodal tissue in sugarcane Austr J Plant Physiol 27 (1): 81-85.

Bradford MM. 1976. A rapid, sensitive method for the quantitation of microgram quantities of protein utilizing the principle of protein-dye binding Anal Biochem 72: 248-256. DOI: 10.1016/0003-2697 (76) $90527-3$

Buijitsse B, Feskens EJM, Kok FJ, Kromhout D. 2006. Cocoa intake, blood pressure, cardiovascular mortality. J Arch Internal Med 166 (4): 411-417. DOI: 10.1001/archinte.166.4.411.

Colla G, Rouphael Y, Cardarelli M, Tullio M, Rivera CM, Rea E. 2008. Alleviation of salt stress by arbuscular mycorrhizal in zucchini plants grown at low, high phosphorus concentration. Biol Fertil Soils 44: 501-509.

Cristobal JJC, Gonzalez-Fontes A. 1999. Boron deficiency causes a drastic decrease in nitrate content, nitrate reductase activity, increases the content of carbohydrates in leaves from tobacco plants. Planta 209: 528-536. .

Engler MB, Engler MM, Chen CY, Malloy MJ, Brownes A, Chiu EY, Kwak HK, Milburry P, Paul SM, Blumberg J, Sndyder M. 2004. Flavonoid-Rich dark chocolate improves endothelial function, increases plasma epicatechin concentrations in healthy adults. J Amer Coll Nutr 23 (3): 197-204

Eraslan F, Inal A, Gunes A, Alpaslan M. 2007. Boron toxicity alters nitrate reductase activity, proline accumulation, membrane permeability, mineral constituents of tomato, pepper plants. J Plant Nutr 30: 981-994. DOI: 10.1080/15226510701373221. 
Giri B, Mukerji K. 2004. Mycorrhizal inoculant alleviates salt stress in Sesbania aegyptiaca, Sesbania grandiflora under field conditions: evidence for reduced sodium, improved magnesium uptake. Mycorrhiza 14: 307-312.

Grassi D, Necozione S, Lippi C, Croce G, Valeri L, Pasqualetti P, Desideri G, Blumberg JB, FerriC. 2005. Cocoa reduces blood pressure, insulin resistance, improves endothelium-dependent vasodilation in hypertensives. J Hypertension 46: 308-405. DOI: 10.166/01/hyp.0000174990.46027.70

Guehi TS, Dingkuhn M, Cros E, Fourny G, Ratomahenina R, Moulin G, Clement A. 2007. Identification, lipase-producing abilities of Moulds Isolate from Ivorian raw cocoa beans res. J Agric Biol Sci 3: 838-843.

Gunalan G, Subhasini R, Mahadeva Rao US, Sumathi P. 2010. A Comparative phytochemical analysis of cocoa, green tea. Indian J Sci Technol 3 (2): 188-192.

Harbone JB. 1987. Metode Fitokimia, Penerbit ITB, Bandung. [Indonesia]

Hegazi S, El-Motaium RA, Yehia TA, Hashim ME.2018. Effect of foliar boron application on boron, chlorophyll, phenol, sugars, hormones concentration of olive (Olea europaea L.) buds, leaves, fruits, J Plant Nutr., DOI: 10.1080/01904167.2018.1425438.

Hemantaranjan A, Trivedi KA. 2015 Influence of boron, zinc on nitrate, nitrite reductase activity in roots, leaves, sulfur-containing amino acids, protein, oil content in seeds of soybean (Glycine Max (L.) Merr.). Intl J Sci Res Sci Technol 1 (3): 30-38.

Hu W, Coomer TD, Loka DA, Oosterhuis DM, Zho Z. 2017. Potassium deficiency affects the carbon-nitrogen balance in cotton leaves. Plant Physiol Biochem 155: 408-417. DOI: 10.1016/j.plaphy.2017.04.005

Humphries EC. 1943. Wilt of cacao fruits (Theobroma cacao L.) II. A Preliminary Survey of the carbohydrate metabolism with special reference to wilt susceptibility. Ann Bot 7: 45-46.

Humphries EC. 1947. Wilt of cacao fruits (Theobroma cacao): IV Seasonal variation in the carbohydrate reserves of the bark, wood of the cacao tree. Ann Bot 11 (42): 221-244

Humphries EC. 1950. Wilt of cacao fruits (Theobroma cacao): V. Seasonal variation in potassium, nitrogen, phosphorus, calcium of the bark, wood of the cacao tree. Ann Bot 14 (54): 149-164.

Jiang H, Yang MJ, Zhang CJF. 2007. Effect of external phosphorus on the cell ultrastructure, the chlorophyll content of maize under cadmium, zinc stress. Environ Pollut 147: 750-756.

Kastori R, Petrovic N. 1989. Effect of boron on nitrate reductase activity in young sunflower plants. J Plant Nutr 12 (5): 621-632.

Keen C., Holt RR, Otieza PI, Fraga CG and. Schmitz HH. 2005. Cocoa antioxidant, cardiovascular health. Amer J Clin Nutr 81: 298S-303S.

Kim J, Lee KW, Lee HJ. 2011. Cocoa (Theobroma cacao) seeds, phytochemicals in human health. In: Nuts and Seeds in Health and Disease Prevention. Elsevier, New York.

Kitir N, Gunes A, Turan M, Yildirim E, Topcuoglu B, Turker M Ozlu E, Karaman MR, Firıldak G. 2018. Bio-boron fertilizer applications affect amino acid, organic acid content, physiological properties of strawberry plant. Erwerbs-Obstbau-Springer, Nederlands. DOI: 10.1007/s10341-018-0409-3

Marschner H. 2012. Mineral Nutrition of Higher Plants. 3rd ed. Elsevier, New York.
McKelvie AD. 1956. Cherelle wilt of cacao. I. Pod development, its relation to wilt. J Exp Bot 7: 252-263.

McKelvie AD. 1960. Cherelle wilt of cacao: II. Wilt in relation to yield. J Exp Bot 11 (33): 413-424

Melnick LR, Strem DM, Rozier J, Sicher CR, Bailey BA. 2013. Molecular, metabolic changes of cherelle wilt of cacao, its effect on Moniliophthora roreri. Physiol Mol Plant Pathol 84: 153-162.

Nichols, R. 1961. Xylem occlusions in the fruit of cacao (Theobroma cacao), their relation to cherelle wilt. Ann Bot 25 (100): 463-475.

Olsen SR, Sommers LE. 1982. Phosphorous. In: Page AL. (ed.), Methods of Soil Analysis (Part 2): Chemical, Microbiological Properties. American Society of Agronomy, Madison, USA.

Percey WJ, Shabala L, Wu Q, Su N, Breadmore MC, Guijt RM, J Bose J, Shabala S. 2016. Potassium retention in leaf mesophyll as an element of salinity tissue tolerance in halophytes. Plant Physiol Biochem. DOI: $10.1016 /$ j.plaphy.2016.10.011.

Pound FJ. 1932. Studies of fruitfulness in cacao. II. Evidence for partial sterility. First Annuals on Cacao Research, 26-21.

Prawoto A. 2000. Kajian morfologis, anatomis dan biokhemis layu pentil kakao serta perkembangan upaya pengendalian. Pelita Perkebunan 16 (1): 11-29. [Indonesian]

Ringel P, Krausze J, Heuve JVD, Curth U, Pierik AJ, Herzog S, Mendel RR, Kruse T. 2013. Biochemical characterization of molybdenum cofactor-free nitrate reductase from Neurospora crassa. J Biol Chem 288 (20); 14657-14671.

Roventos RML, Perez AIR, Lacueva AA, Torner A. 2005. Review: Health Effects of cocoa flavonoids. J Food Sci Technol Intl 11: 159-176. DOI: $10.1177 / 1082013205054498$.

Steinberg FM, Bearden MM, Keen CL. 2003. Cocoa, chocolate flavonoids: implications for cardiovascular health. J Amer Dietic Assoc 103: 215-223.

Taiz L, Zeiger E. 2006. Plant Physiology. $4^{\text {th }}$ ed. Sinauer Associates, Inc., Sunderland, MA.

Wachjar A. 2005. Kajian tanggap fisiologis perkembangan buah muda dan layu pentil terhadap pemberian unsur seng ( $\mathrm{Zn}$ ) dan boron (B) serta pengaruhnya terhadap hasil kakao (Theobroma cacao L.). [Dissertation]. Institut Pertanian Bogor, Bogor. [Indonesia]

Yu SM, Lo SF, Ho THD. 2015. Source-sing communications: Regulated by hormone, nutrient, stress cross-signaling. Trends Plant Sci 20 (12): 844-857. DOI: DOI: 10.1016/j.tplants.2015.10.009.

Zakariyya F, Prawoto AA. 2015. Stomatal conductance, chlorophyll characteristics, their relationship with yield of some cocoa clones under Tectona grandis, Leucaena sp., Cassia surattensis. Pelita Perkebunan 31 (2): 99-108. [Indonesia\}

Zhang J, Wang Y, Wang P, Zang QA, Yan C, Yu F, Yu J, Fang J. 2017. Effect of different levels of nitrogen, phosphorus, potassium on root activity, chlorophyll content in leaves of Brassica oleracea seedlings grown in vegetable nursery substrate. Horticult Environ Biotechnol. DOI: 10.1007/s13580-017-0177-2.

Zhao XH, Du Q, Zhao Y, Wang HJ, Li YJ, Wang XG., Yu HQ. 2016. Effects of different potassium stress on leaf photosynthesis, chlorophyll fluorescence in maize (Zea mays L.) at seedling stage. Agric Sci 7: 44-53. DOI: 10.4236/as.2016.71005. 